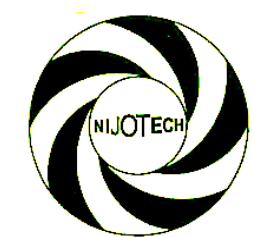

Nigerian Journal of Technology (NIJOTECH)

Vol. 39, No. 1, January 2020, pp. 42 - 51

Copyright@ Faculty of Engineering, University of Nigeria, Nsukka

Print ISSN: 0331-8443, Electronic ISSN: 2467-8821

www.nijotech.com

http://dx.doi.org/10.4314/njt.v39i1.5

\title{
EFFECT OF SOIL COMPRESSIBILITY ON THE STRUCTURAL RESPONSE OF BOX CULVERTS USING FINITE ELEMENT APPROACH
}

\author{
O. U. Ubani ${ }^{1, *}$, C. M. O. Nwaiwu ${ }^{2}$, J. I. Obiora ${ }^{3}$ and E. O. Mezie ${ }^{4}$ \\ $\mathbf{1 , 2 , 3 , 4}$, DePARTMENT OF Civil ENGINEERING, NNAMdi AZIKIWE UNIVERSITY, AWKA, ANAMBRA STATE, NIGERIA \\ E-mail addresses: 1 ou.ubani@unizik.edu.ng, ${ }^{2}$ cmo.nwaiwu@unizik.edu.ng, \\ 3ij.obiora@unizik.edu.ng, 4 eo.mezie@unizik.edu.ng
}

\begin{abstract}
The structural response of box culverts to variable soil compressibility condition was studied in this paper. This was made possible by modelling the soil as springs, and varying the spring stiffness which was represented by the modulus of subgrade reaction of the soil. The results showed that the values of maximum bending moments for gravity actions on box culverts increased linearly with modulus of subgrade reaction, but remained within close values. The results also showed good agreement with results from literature for highly compressible soils. However, for incompressible soil condition, results from standard tables in literature were more conservative with about $10 \%$ difference for gravity actions, and $21 \%$ difference for lateral actions. The term 'highly compressible' that was used in literature for manual analysis was discovered to be more valid for lateral load cases than for gravity load cases. Subsequently, the variations of other action effects such as shear force, axial force, torsion, and soil spring settlement with modulus of subgrade reaction were also studied.
\end{abstract}

Keywords: Box Culvert, Modulus of Subgrade Reaction, Soil Settlement, Staad Pro.

\section{INTRODUCTION}

Culverts are structures designed to convey stream or storm water of limited flow across a roadway. Box culvert is a type of culvert that is made of reinforced concrete consisting of two side walls, a top slab, and a bottom slab which are all monolithically connected. In practice, box culverts could be made from factory precast elements and installed on site, or could be cast in-situ. The geometry, location, and alignment of box culverts are usually based on hydraulic considerations, so that a flood of a specified design period can be conveniently conveyed without overflowing or submerging the structure or the roadway.

Since culverts are buried across the transverse direction of the road way, they are subjected to the same traffic actions encountered by the pavement. Generically, culverts are subjected to traffic actions from moving vehicles, vertical earth pressure from cushion (earth fill), lateral earth pressure from backfill soil, hydrostatic pressure from ground water, uplift, braking and acceleration forces, partial or full internal water pressure when the culvert is in operation, and other direct and indirect actions. When a culvert is deeply buried under the ground at a depth exceeding $600 \mathrm{~mm}$ from the crown of the roadway, traffic wheel load is dispersed on the top slab of the structure as a uniformly distributed load [1]. On the other hand, when the top slab of the box culvert is covered by an earth fill with thickness less than $600 \mathrm{~mm}$, the wheel load is applied directly on the carriageway. Wheel load is usually dispersed through the earth fill using the popular 2:1 method $[1,2]$. The nature and magnitude of loading applied depends on the site conditions and the code of practice being employed for the design. However, [3] have reported that stresses in a buried box culvert are redistributed due to the phenomenon of soil arching, which is mainly caused by the presence of a rigid body inside a deformable body. Therefore, soil-structure interaction is important in the study of the behaviour of box culverts for safe and economical designs.

* Corresponding author, tel: +234 8060307054 
Reynolds et al. [4] published equations which are based on moment distribution method for analysis of rectangular culverts subjected to different load regimes when supported by highly compressible and non-compressible soils. The equations published therein starting from the earlier editions of the book have been widely applied in many civil engineering design of box culverts. However, it is widely acknowledged that the use of commercial software for the purpose of analysis and design of structures is now widespread. These software are used in most design offices for obtaining the effects of actions in diverse structures whether by considering one dimensional, two dimensional, or three dimensional modelling.

Staad Pro software has been widely applied by many researchers for structural analysis of box culverts [58]. Shende and Shudare [9] have investigated the effects of aspect ratio $(\mathrm{L} / \mathrm{h})$ and variable angle of internal friction on the structural response of box culverts. Ahmed and Alarabi [2] compared the manual analysis of box culverts with Prokon software, and obtained values which were in close agreement with results and the coefficients provided in Table 186 of Reynolds and Steedman [10] for highly compressible soils.

As recommended by [1], an elastic compressible support may be assumed below the base slab of box culverts except when the structure is founded on hard material. When the foundation is founded on a compressible support, the foundation is regarded as flexible, while in the latter case, the foundation is regarded as rigid. The document further recommended that for portal structures where the moments in the frames are sensitive to rotational stiffnesses of the foundations, two separate analyses should be carried out - one considering flexible, and the other rigid foundation. While simple idealisations that are suited for hand calculations can be employed for rigid support conditions, it is extremely challenging to use hand calculations for flexible foundation analysis. As a result, finite element method can be used for analysis of flexible foundations.

Staad Pro software supports the use of flexible foundations by the use of 'plate mat' or 'elastic mat' foundation option $[11,12]$. In these support options, soils are modelled as springs whose properties are defined using the subgrade modulus of the soil (units in $\mathrm{kN} / \mathrm{m}^{2} / \mathrm{m}$ ). The springs are attached to the nodes, and the tributary area of each node is multiplied by the modulus of subgrade reaction, to obtain the linear elastic spring constant (units in $\mathrm{kN} / \mathrm{m}$ ) which is used in the finite element analysis carried out by the software. A schematic representation of tributary area for node 2 of a plate element is as shown in Figure 1.

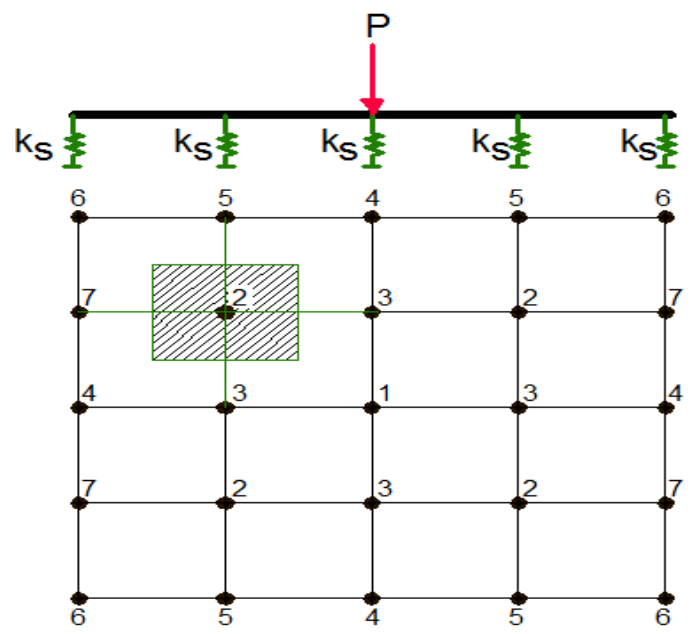

Fig. 1: Typical model of a plate on grade supported on soil springs

The mathematical expression for modulus of subgrade reaction $\left(k_{s}\right)$ is given by equation (1);

$$
k_{s}=q / s
$$

Where $q$ is the applied pressure $\left(\mathrm{kN} / \mathrm{m}^{2}\right)$ and $S$ is the settlement $(m)$ of the soil.

According to [13], the simplest representation of a foundation subgrade is by the use of Winkler's model, in which soils are represented using linear springs that are independent of each other. Mathematically, Winkler's model is given by equation (2);

$$
p(x, y)=k_{s} w_{0}(x, y)
$$

Where $p$ is the vertical contact pressure at an arbitrary point $(x, y), k_{\mathrm{s}}$ is the coefficient of subgrade reaction, and $w_{0}$ is the corresponding vertical settlement at the point. This is the same approach used by Staad Pro software.

Generally, the value of $k_{s}$ may be obtained from laboratory tests, field tests, empirical relations or from tabulated values. Several authors have established relationships for estimating the value of the modulus of subgrade reaction of a soil. One of the most popular relationships between allowable bearing capacity and modulus of subgrade reaction is given in equation (3) according to [14];

$$
k_{\mathrm{s}}=40 .(\mathrm{FS}) \cdot\left(q_{\mathrm{a}}\right)
$$


Where $q_{\mathrm{a}}$ is the allowable bearing capacity of the soil, and FS is the factor of safety that was used in converting the ultimate pressure (qult) to allowable pressure $\left(q_{a}\right)$. It is important to note that in equation (3), the author assumed $25 \mathrm{~mm}$ settlement of the soil. Other researchers such as [15] presented equations for prediction of modulus of subgrade reaction of clayey soils from unconfined compression tests.

Walker and Holland [16] however reported that modulus of subgrade reaction is one of the most misunderstood parameters used by engineers in the design of slabs-on-grade. It is usually assumed that the value of the parameter is an exclusive inherent property of the soil, but several authors have shown that the value of coefficient of subgrade reaction depends on the size of the loaded area. As a result, $k_{s}$ values obtained from in-situ plate load tests or other equivalent tests will need to be corrected for shape and size. Furthermore, a commonly reported short coming of Winkler's model is the uncoupled behaviour of the springs, which means that the deformation of a spring is independent of each other $[13,16]$. The physical interpretation of this is that displacement at one location does not influence displacement at another location, which is not correct for displacement in elastic soils (see Figure 2). Murthy [17] however suggested that using modulus of subgrade reaction gives realistic values of base pressure, especially when low values of settlement are anticipated.

A little review by the authors on the behaviour of Staad Pro has shown that this limitation of the Winkler's model was overcame by the software by considering the tributary area of each spring (see example on node 2 of Figure 1), which extends to all the plates surrounding each node. To verify this, a $150 \mathrm{~mm}$ thick $(1 \mathrm{~m} \times 1 \mathrm{~m})$ plate with 4 divisions on each side was supported on an elastic soil spring of subgrade modulus of $10000 \mathrm{kN} / \mathrm{m}^{2} / \mathrm{m}$ and subjected to a concentrated force of $50 \mathrm{kN}$ at the central node. A saddle shaped deformation was obtained with the relative values of compression shown for each node as given in Figure 3.

Therefore, the finite element analysis potentials of Staad Pro software was utilised in this research work to determine the effects of soil compressibility on the structural response of box culverts in terms of internal forces (bending, shear, and axial) and base pressure.

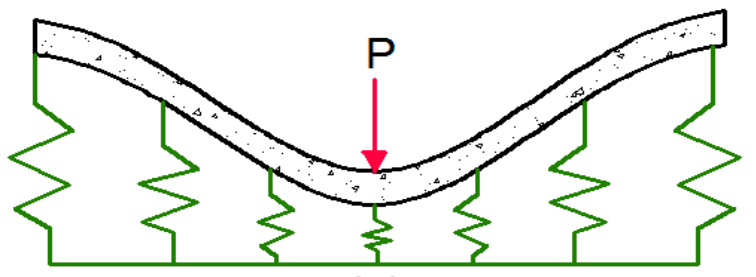

(a)

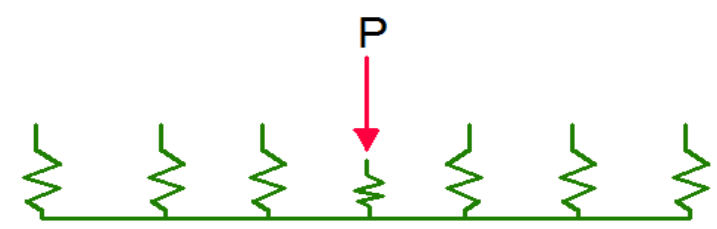

(b)

Fig. 2: (a) Typical model of a coupled soil spring (b) Typical behaviour of an uncoupled soil spring system

This work is aimed at providing an insight to design engineers on the effect of variable soil properties (variable vertical soil settlement values) on the structural response of box culverts. The specific objectives are to compare the variation of design internal forces (bending moment, shear force, axial force, and torsion) with different support settlement values. With this knowledge, design engineers will know the effect of variable soil compressibility values on structural behaviour of box culverts, instead of being limited to the extremes of 'highly compressible' and 'non-compressible' soils available in most design textbooks.

\section{METHODOLOGY}

In this work, a box culvert of height $2 \mathrm{~m}$ and width $2.5 \mathrm{~m}$ (based on centre to centre dimensions) was subjected to different load regimes that could be encountered in practice. The thickness of the top and bottom slabs was taken as $250 \mathrm{~mm}$, while the thickness of the walls was taken as $300 \mathrm{~mm}$. The box culvert was modelled considering a metre length, and the plate elements in the model were divided into square meshes of dimensions $0.25 \mathrm{~m} \times 0.25 \mathrm{~m}$. The culvert was subjected to four load cases as shown in Table 1 . Since the loading on box culverts could vary depending on the site conditions and the code of practice used, arbitrary values of loads have been used to demonstrate the effects of variable soil compressibility.

The compressibility of the soil was varied from very soft to very hard using the values of modulus of subgrade reaction as a reference, and the results obtained were compared with the results from Table 
186 of [10] and Table 2.87 of [4]. Insight on the values of modulus of subgrade reaction has been picked from the values offered by A.A. Alexandrou of University of Greenwich, reported by [19]. The values are given in Table 2 .

Bowles [12] also suggested some range of values of modulus of subgrade reaction and the abridged version is given in Table 3.

In this study, the modulus of subgrade reaction was varied to represent different classes of soils that could be encountered by engineers as follows; $5000 \mathrm{kN} / \mathrm{m}^{2} / \mathrm{m}, \quad 20000 \mathrm{kN} / \mathrm{m}^{2} / \mathrm{m}, \quad 50000 \mathrm{kN} / \mathrm{m}^{2} / \mathrm{m}$, $75000 \mathrm{kN} / \mathrm{m}^{2} / \mathrm{m}, 100000 \mathrm{kN} / \mathrm{m}^{2} / \mathrm{m}, 150000 \mathrm{kN} / \mathrm{m}^{2} / \mathrm{m}$, $200000 \mathrm{kN} / \mathrm{m}^{2} / \mathrm{m}, 300000 \mathrm{kN} / \mathrm{m}^{2} / \mathrm{m}$ and fully fixed support condition. These variable soil conditions have been applied for all the load cases studied.

\section{ANALYSIS AND RESULTS}

On considering the 3D analysis of the box culvert utilising plate elements and variable support conditions, the bending moments, shear forces, axial forces, and soil settlement are presented for different load cases in this section. The internal forces obtained in the box culvert due to variable modulus of subgrade reaction for Load Case 1 is given in Table 4 , while the variation of soil spring settlement with modulus of subgrade reaction is shown in Figure 5. For the purpose of clarity in the distribution of internal forces, it could be clearly seen from Figure 4 that the bending moment contour of the shell shows similarity to the one proposed in Table 186 of Reynolds and Steedman [10] for uniformly distributed load on the top slab of a culvert on compressible soil. Due to the externally applied load, the culvert side walls were subjected to a constant bending moment value of $17.748 \mathrm{kNm} / \mathrm{m}$, which is comparable to $17.801 \mathrm{kNm}$ obtained from Reynolds and Steedman [10]. A minimal sagging moment of $2.22 \mathrm{kNm}$ was observed at the midspan from Staad Pro.

A study of Table 4 shows that there was no significant variation of bending moment provided there was soil settlement. The greatest difference in magnitude of soil settlement was observed when the modulus of subgrade reaction was increased from $5000 \mathrm{kN} / \mathrm{m}^{2} / \mathrm{m}$ to $20000 \mathrm{kN} / \mathrm{m}^{2} / \mathrm{m}$ with a reduction in settlement of about $76 \%$ (see Figure 5). Despite this huge difference in settlement value, the difference in bending moment value was found to be $0.09 \%$. However, a general slight increment in values of bending moment was observed as the soil modulus of subgrade reaction increased. The difference in bending moment value from $k_{\mathrm{s}}$ value of 5000 $\mathrm{kN} / \mathrm{m}^{2} / \mathrm{m}$ to $300000 \mathrm{kN} / \mathrm{m}^{2} / \mathrm{m}$ was found to be just $1.26 \%$. Also, for compressible support conditions, the variation of bending moment with modulus of subgrade reaction was found to be linear. It is also pertinent to point out that considerable value of longitudinal bending moment $\left(M_{y}\right)$ was observed at the mid-span, which designers should look out for when carrying out analysis..

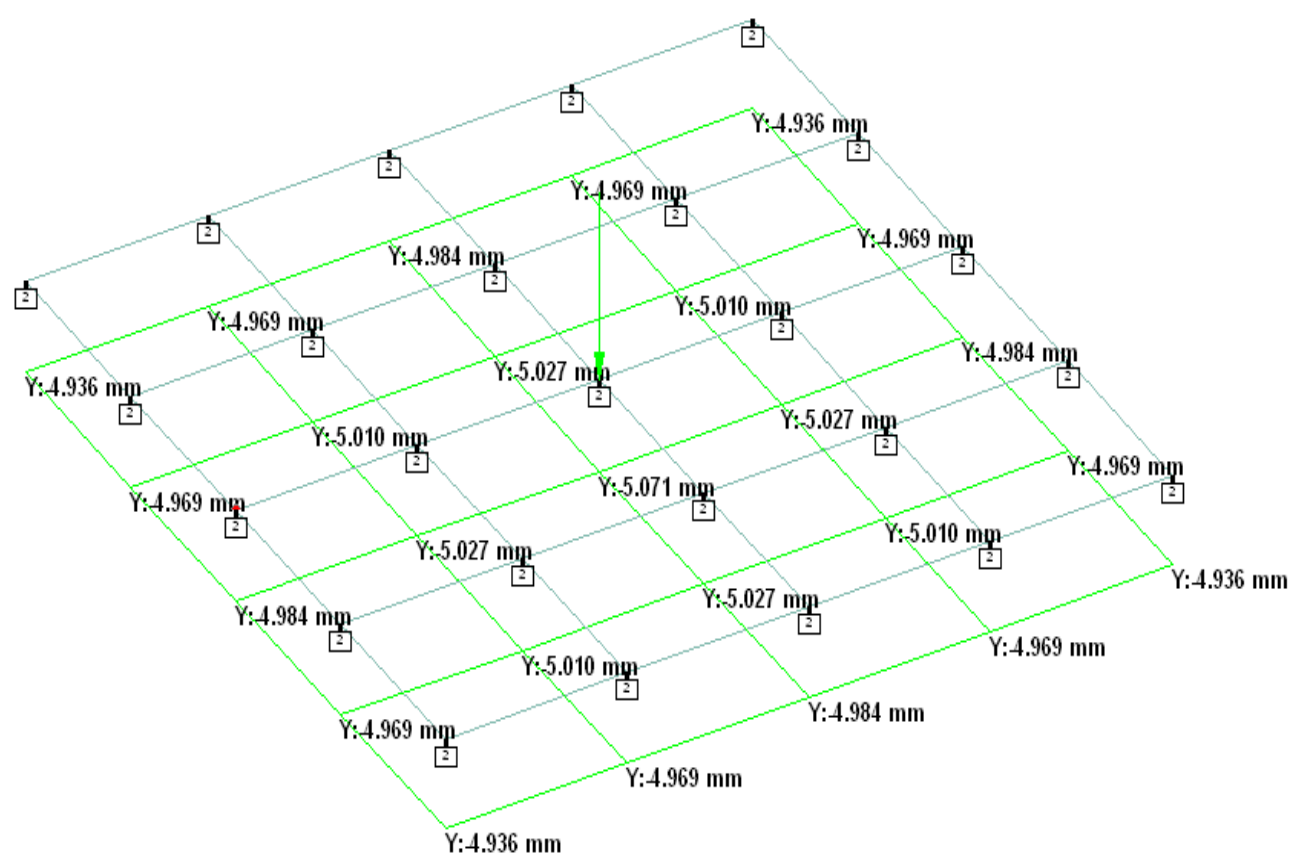

Fig. 3: Staad Pro model of relative displacement of slab on grade supported on soil springs 
Table 1: Load cases considered in the study

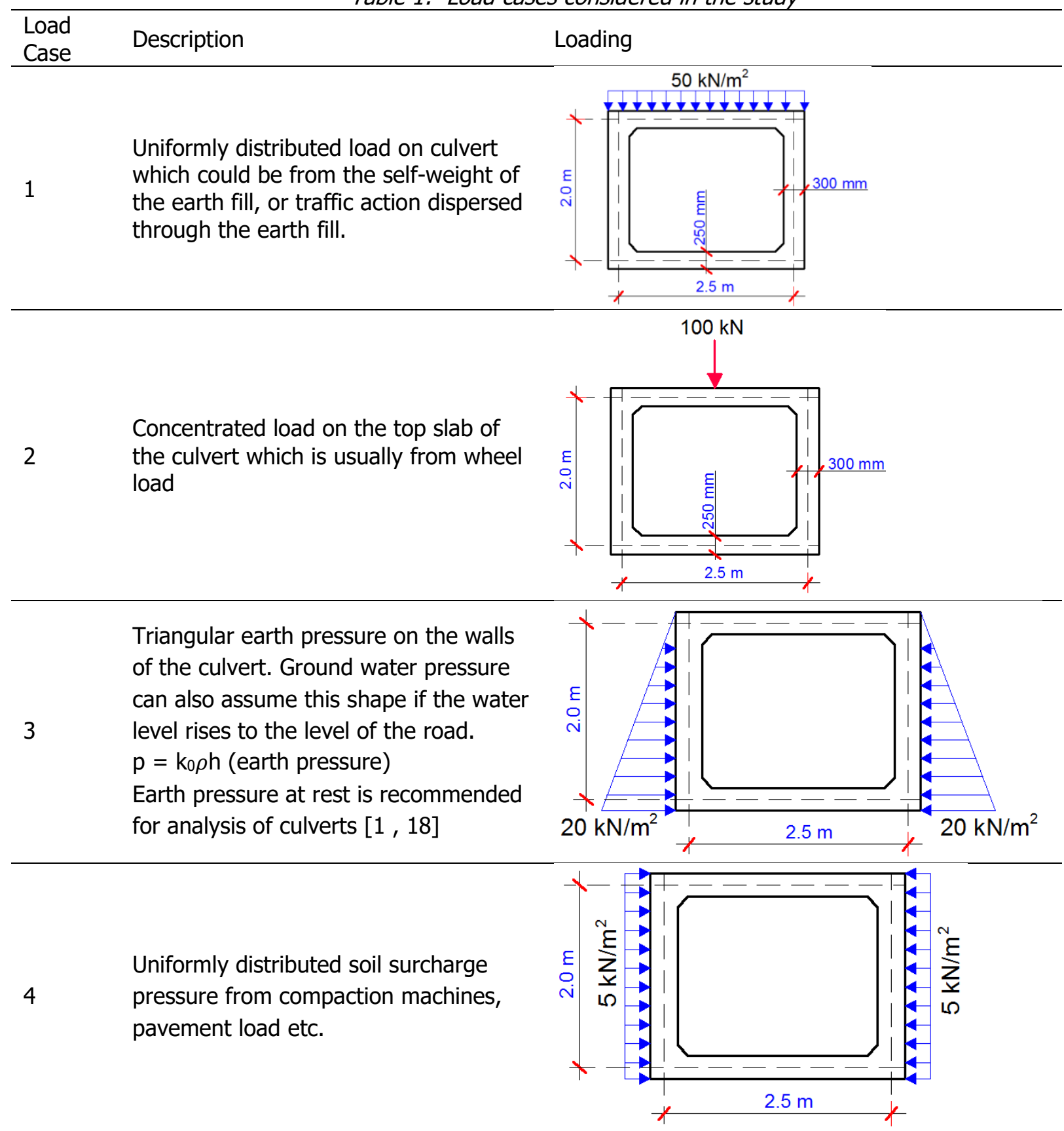

Table 2: Values of modulus of subgrade reaction for different soils Source: [17]

\begin{tabular}{ll}
\hline Soil Description & $k_{\mathrm{s}}\left(\mathrm{kN} / \mathrm{m}^{2} / \mathrm{m}\right)$ \\
\hline Humus soil or peat & $5000-15000$ \\
Recent embankment & $10000-20000$ \\
Fine or slightly compacted soil & $15000-30000$ \\
Well compacted sand & $50000-100000$ \\
Very well compacted sand & $100000-150000$ \\
Loam or clay (moist) & $30000-60000$ \\
Loam or clay (dry) & $80000-100000$ \\
Clay with sand & $80000-100000$ \\
Crushed stone with sand & $100000-150000$ \\
Coarse crushed stone & $200000-250000$ \\
Well compacted crushed stone & $200000-300000$ \\
\hline
\end{tabular}

Table 3: Values of modulus of subgrade reaction for different soils

\begin{tabular}{ll}
\hline Soil Description & $k_{\mathrm{s}}\left(\mathrm{kN} / \mathrm{m}^{2} / \mathrm{m}\right)$ \\
\hline Loose sand & $4800-16000$ \\
Dense sand & $64000-128000$ \\
Clayey soil $\left(q_{\mathrm{a}}<200 \mathrm{kPa}\right)$ & $12000-24000$ \\
Clayey soil $\left(q_{\mathrm{a}}>800 \mathrm{kPa}\right)$ & $48000-200000$ \\
\hline
\end{tabular}

Source: [12]

For fully fixed support condition, the bending moment value from Staad Pro was found to be $18.917 \mathrm{kNm} / \mathrm{m}$, while the bending moment value from [10] was found to be $21.147 \mathrm{kNm} / \mathrm{m}$ (see Figure 6). Despite this significant difference of about $10.5 \%$ in value, the 
distribution of bending moment in both approaches was found to be similar. The bending moment at the base of the culvert was found to be practically zero, while the bending moment on the walls varied from hogging at the top slab $(18.8 \mathrm{kNm} / \mathrm{m})$ to about 7.05 $\mathrm{kNm} / \mathrm{m}$.

There was no significant variation in the value of shear stress for foundations with compressible support. However for Load Case 1, the value of shear force increased from $5.61 \mathrm{kN} / \mathrm{m}\left(0.0187 \mathrm{~N} / \mathrm{mm}^{2}\right)$ at compressible support to $18.9 \mathrm{kN} / \mathrm{m}\left(0.0626 \mathrm{~N} / \mathrm{mm}^{2}\right)$ at fully fixed support. The axial force in the walls remained constant for all compressible support conditions, and increased by $0.92 \%$ when the foundation was fully fixed.

The variation of internal forces with modulus of subgrade reaction for Load Case 2 is given in Table 5. The same trend in behaviour for bending moment for Load Case 1 was also observed for Load Case 2 with $0.97 \%$ increase in bending moment when the modulus of subgrade reaction was increased from 5000 $\mathrm{kN} / \mathrm{m}^{2} / \mathrm{m}$ to $300000 \mathrm{kN} / \mathrm{m}^{2} / \mathrm{m}$. When the structure was analysed using the method recommended by Reynolds and Steedman [10], the bending moment value obtained at the top edge was found be $22.313 \mathrm{kNm} / \mathrm{m}$, against the $21.687 \mathrm{kNm} / \mathrm{m}$ obtained for the most compressible soil condition of $k_{s}=5000 \mathrm{kN} / \mathrm{m}^{2} / \mathrm{m}$. While this showed good agreement with about $2.8 \%$ difference, the value of bending moment obtained for incompressible soil condition using formula from Reynolds and Steedman [10] was $25.376 \mathrm{kNm} / \mathrm{m}$, against $22.849 \mathrm{kNm} / \mathrm{m}$ obtained using Staad Pro. This gives a difference of about $9.95 \%$. The variation of soil spring settlement with modulus of subgrade reaction for load case 2 is shown in Figure 7. The trend was found to be similar to that of Load Case 1 .
For lateral actions (Load Cases 3 and 4), a study of the stress contours from Staad Pro has shown that the critical moments are given in the $M_{y}$ section due to the orientation of the loading. Generally, the vertical moments obtained for compressible soil conditions increased with the modulus of subgrade reaction. The bending moment obtained under low modulus of subgrade reaction showed good agreement with the formula in Reynolds and Steedman [10] for highly compressible soil (see Figure 8 and Table 6). The difference in the value of bending moment when the modulus of subgrade reaction was increased from $5000 \mathrm{kN} / \mathrm{m}^{2} / \mathrm{m}$ to $300000 \mathrm{kN} / \mathrm{m}^{2} / \mathrm{m}$ was found to be $21.5 \%$. The difference in the result of the bending moment at the top of culvert was found to be $0.78 \%$ for $k_{\mathrm{s}}$ value of $5000 \mathrm{kN} / \mathrm{m}^{2} / \mathrm{m}$. For uncompressible soil condition, the bending moment was found to be $0.5011 \mathrm{kNm} / \mathrm{m}$ using formula from Reynolds and Steedman [10], and $0.586 \mathrm{kNm} / \mathrm{m}$ using Staad Pro thereby giving a difference of about $14.5 \%$.

The same trend in behaviour for Load Case 3 was also observed for Load Case 4 as shown in Table 7. The vertical moment was found to increase with the modulus of subgrade reaction and the difference in the value of bending moment when the modulus of subgrade reaction was increased from $5000 \mathrm{kN} / \mathrm{m}^{2} / \mathrm{m}$ to $300000 \mathrm{kN} / \mathrm{m}^{2} / \mathrm{m}$ was found to be $21.65 \%$. When the formula from [10] for highly compressible soils was used, the maximum moment at the roof of the culvert was found to be $0.527 \mathrm{kNm} / \mathrm{m}$, against $0.539 \mathrm{kNm} / \mathrm{m}$ obtained on Staad Pro. For incompressible soil condition, the value of bending moment obtained was $0.313 \mathrm{kNm} / \mathrm{m}$ against $0.284 \mathrm{kNm} / \mathrm{m}$ obtained on Staad Pro, thereby giving a difference of about $9.265 \%$.

Table 4: Action effects for Load Case 1 under variable soil conditions

\begin{tabular}{lccccccc}
\hline \multirow{2}{*}{$\begin{array}{l}\text { Modulus of Subgrade reaction } \\
\left(\mathrm{kN} / \mathrm{m}^{2} / \mathrm{m}\right)\end{array}$} & \multicolumn{3}{c}{$\begin{array}{c}\text { Bending Moment } \\
(\mathrm{kN} \cdot \mathrm{m} / \mathrm{m})\end{array}$} & \multicolumn{2}{c}{$\begin{array}{c}\text { Shear Stress } \\
\left(\mathrm{N} / \mathrm{mm}^{2}\right)\end{array}$} & \multicolumn{2}{c}{$\begin{array}{c}\text { Axial Force } \\
(\mathrm{kN} / \mathrm{m})\end{array}$} \\
\cline { 2 - 8 } & $M_{\mathrm{x}, \max }$ & $\mathrm{M}_{\mathrm{y}, \max }$ & $\mathrm{M}_{\mathrm{xy}}$ & $\mathrm{Q}_{\mathrm{x}, \max }$ & $\mathrm{Q}_{\mathrm{y}, \max }$ & Wall & Slab \\
\hline 5000 & 17.748 & 20.632 & 1.210 & 0.0187 & 0.231 & 64.20 & 3.25 \\
20000 & 17.764 & 20.585 & 1.191 & 0.019 & 0.230 & 64.20 & 3.25 \\
50000 & 17.794 & 20.508 & 1.159 & 0.019 & 0.230 & 64.20 & 3.25 \\
75000 & 17.817 & 20.558 & 1.134 & 0.0203 & 0.230 & 64.20 & 3.25 \\
100000 & 17.833 & 20.389 & 1.109 & 0.0208 & 0.230 & 64.20 & 3.25 \\
150000 & 17.878 & 20.283 & 1.065 & 0.0217 & 0.229 & 64.20 & 3.25 \\
200000 & 17.914 & 20.188 & 1.026 & 0.022 & 0.229 & 64.20 & 3.25 \\
300000 & 17.974 & 20.025 & 0.958 & 0.0239 & 0.229 & 64.20 & 3.25 \\
Fully fixed & 18.917 & 17.489 & 0.762 & 0.0626 & 0.226 & 64.80 & 2.75 \\
\hline
\end{tabular}



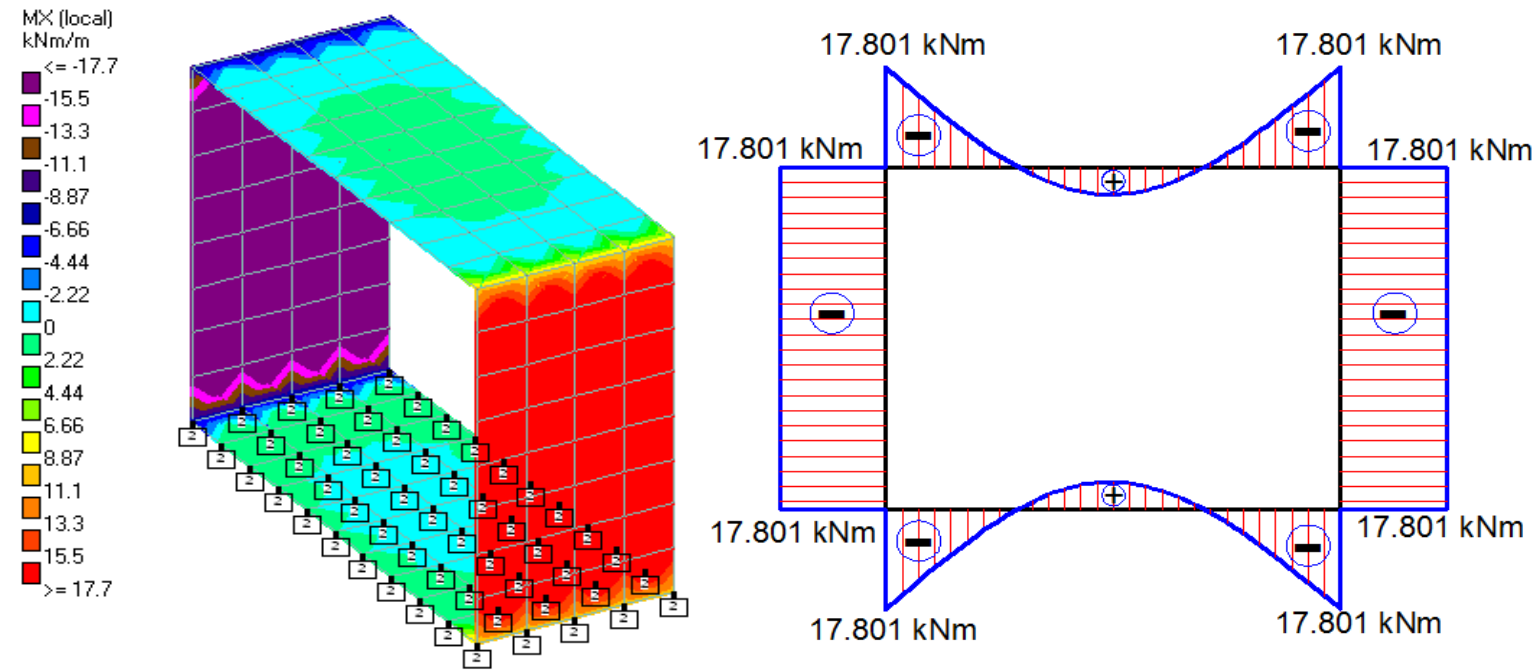

Fig. 4: (a) Bending moment on the culvert for load case $1(\mathrm{ks}=5000 \mathrm{kN} / \mathrm{m} 2 / \mathrm{m}$ ) (b) Bending moment on the culvert for highly compressible soil according to the formula in Table 186 of Reynolds and Steedman [10].

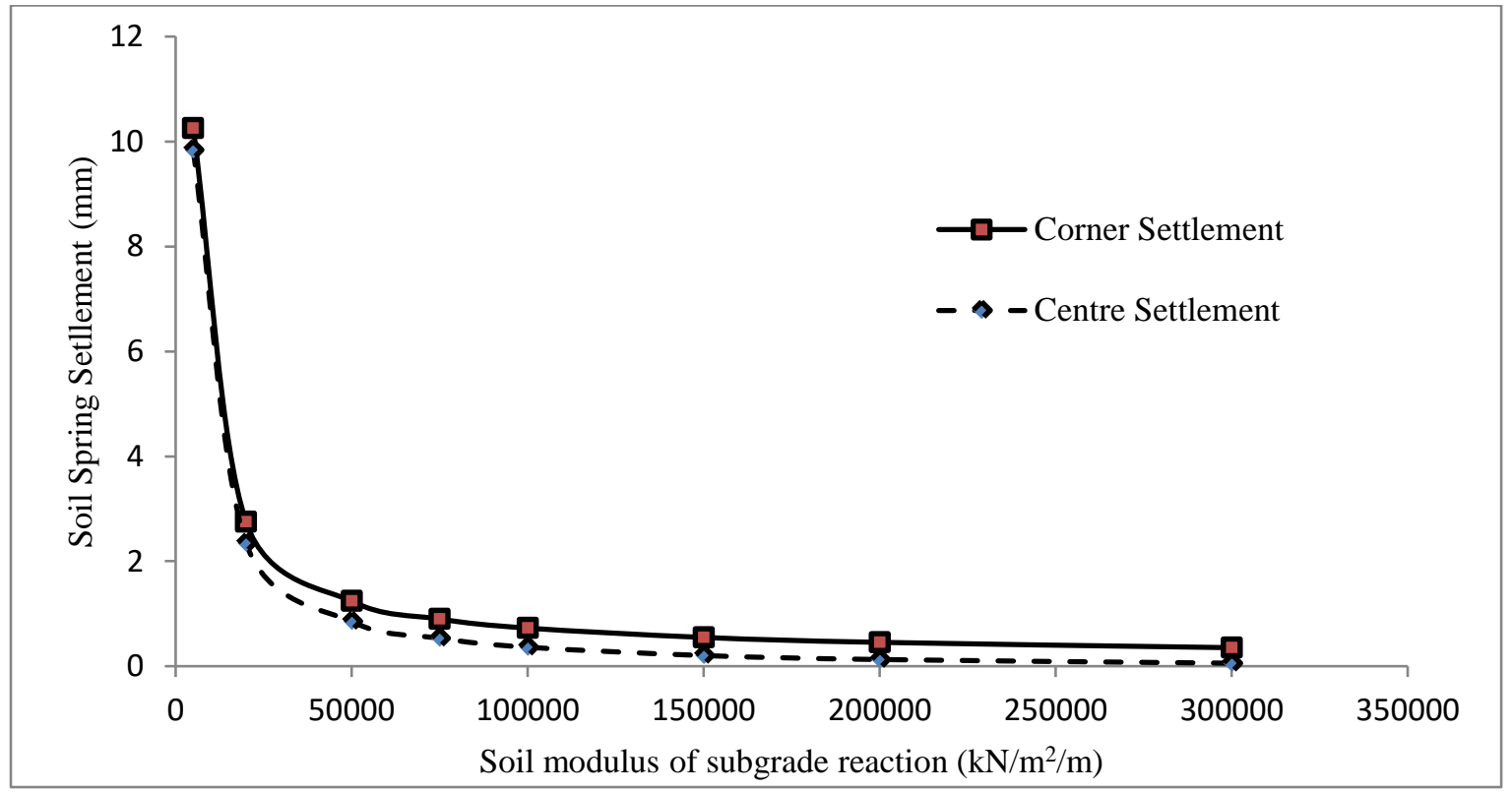

Fig. 5: Variation of soil spring settlement with modulus of subgrade reaction (Load Case 1)

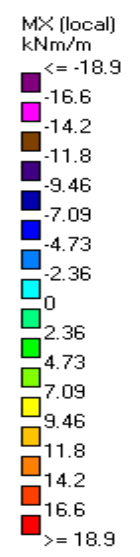

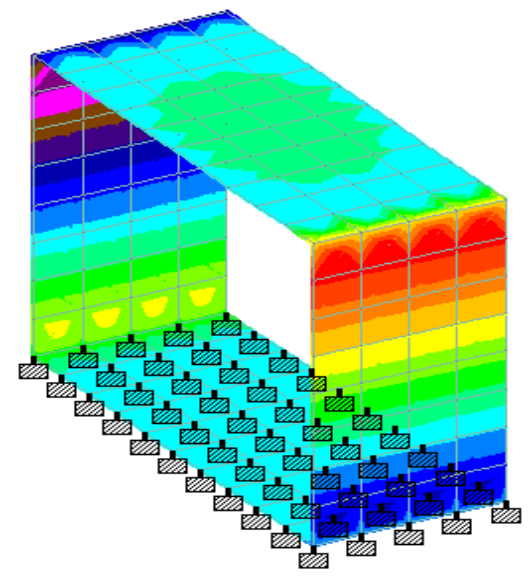

(a)

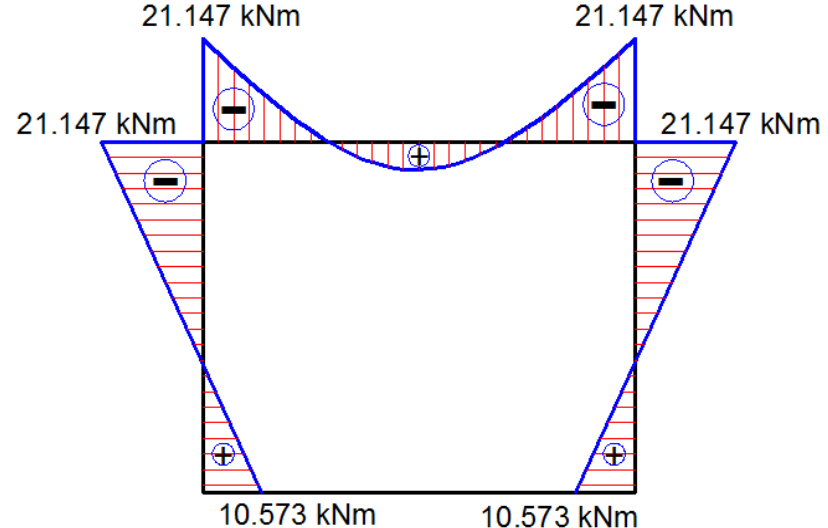

(b)

Figure 6: (a) Bending moment on the culvert for Load Case 1 (fixed support) (b) Bending moment on the culvert for non-compressible support according to the formula in Table 186 of [10] 
Table 5: Action effects of Load Case 2 under variable soil conditions

\begin{tabular}{lccccccc}
\hline \multirow{2}{*}{$\begin{array}{l}\text { Modulus of Subgrade reaction } \\
\left(\mathrm{kN} / \mathrm{m}^{2} / \mathrm{m}\right)\end{array}$} & \multicolumn{3}{c}{$\begin{array}{c}\text { Bending Moment } \\
(\mathrm{kN} . \mathrm{m} / \mathrm{m})\end{array}$} & \multicolumn{2}{c}{$\begin{array}{c}\text { Shear Stress } \\
\left(\mathrm{N} / \mathrm{mm}^{2}\right)\end{array}$} & \multicolumn{2}{c}{$\begin{array}{c}\text { Axial Force } \\
(\mathrm{kN} / \mathrm{m})\end{array}$} \\
\cline { 2 - 8 } & $\mathrm{M}_{\mathrm{x}, \max }$ & $\mathrm{M}_{\mathrm{y}, \max }$ & $\mathrm{M}_{\mathrm{xy}}$ & $\mathrm{Q}_{\mathrm{x}, \max }$ & $\mathrm{Q}_{\mathrm{y}, \max }$ & Wall & Slab \\
\hline 5000 & 21.687 & 35.626 & 1.047 & 0.287 & 0.3369 & 54.60 & 3.250 \\
20000 & 21.702 & 35.589 & 1.032 & 0.287 & 0.3369 & 54.60 & 3.250 \\
50000 & 21.729 & 35.321 & 1.0038 & 0.287 & 0.3369 & 54.60 & 3.250 \\
75000 & 21.751 & 35.468 & 0.981 & 0.287 & 0.3369 & 54.60 & 3.250 \\
100000 & 21.771 & 35.418 & 0.961 & 0.287 & 0.3369 & 54.60 & 3.250 \\
150000 & 21.808 & 35.327 & 0.923 & 0.287 & 0.3369 & 54.60 & 3.250 \\
200000 & 21.841 & 35.245 & 0.913 & 0.287 & 0.3369 & 54.60 & 3.250 \\
300000 & 21.899 & 35.105 & 0.913 & 0.287 & 0.3369 & 54.60 & 3.250 \\
Fully fixed & 22.849 & 32.765 & 0.927 & 0.287 & 0.337 & 55.80 & 3.000 \\
\hline
\end{tabular}

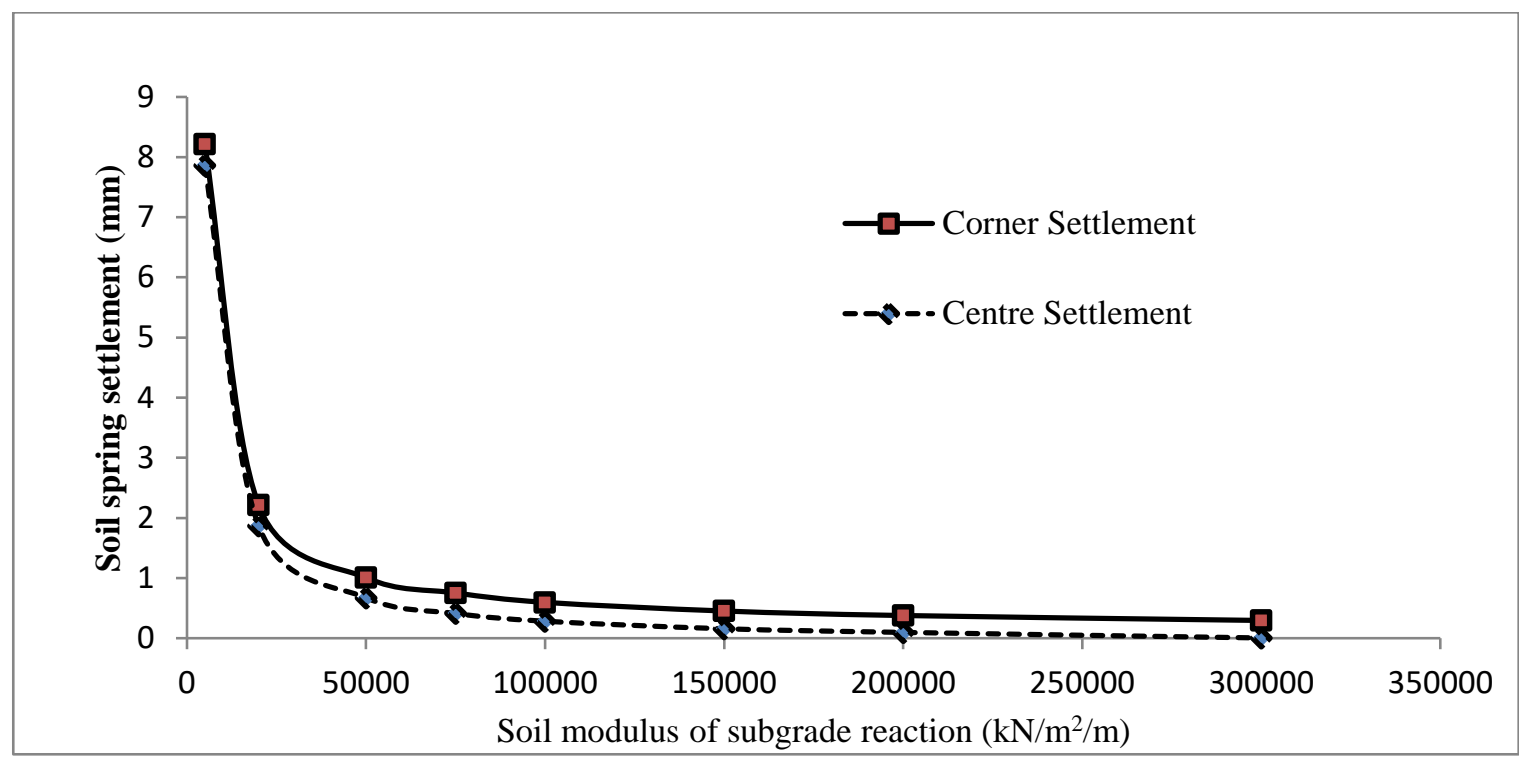

Fig. 6: Variation of soil spring settlement with modulus of subgrade reaction (Load Case 2)

Table 6: Action effects of Load Case 3 under variable soil conditions

\begin{tabular}{lccccccc}
\hline \multirow{2}{*}{$\begin{array}{l}\text { Modulus of Subgrade reaction }\left(\mathrm{kN} / \mathrm{m}^{2} / \mathrm{m}\right) \\
\end{array}$} & \multicolumn{3}{c}{$\begin{array}{c}\text { Bending Moment } \\
(\mathrm{kN} . \mathrm{m} / \mathrm{m})\end{array}$} & \multicolumn{2}{c}{$\begin{array}{c}\text { Shear Stress } \\
\left(\mathrm{N} / \mathrm{mm}^{2}\right)\end{array}$} & \multicolumn{2}{c}{$\begin{array}{c}\text { Axial Force } \\
(\mathrm{kN} / \mathrm{m})\end{array}$} \\
\cline { 2 - 9 } & $\mathrm{M}_{\mathrm{x}, \max }$ & $\mathrm{M}_{\mathrm{y}, \max }$ & $\mathrm{M}_{\mathrm{xy}}$ & $\mathrm{Q}_{\mathrm{x}, \max }$ & $\mathrm{Q}_{\mathrm{y}, \max }$ & Wall & Slab \\
\hline 5000 & 3.986 & 1.156 & 0.2058 & 0.0398 & 0.00133 & 0.468 & 7.000 \\
20000 & 3.972 & 1.179 & 0.2046 & 0.0398 & 0.00149 & 0.489 & 6.900 \\
50000 & 3.946 & 1.221 & 0.206 & 0.0398 & 0.00178 & 0.510 & 6.875 \\
75000 & 3.926 & 1.253 & 0.200 & 0.0398 & 0.00202 & 0.528 & 6.850 \\
100000 & 3.906 & 1.284 & 0.198 & 0.0399 & 0.00224 & 0.543 & 6.850 \\
150000 & 3.871 & 1.339 & 0.195 & 0.0397 & 0.00288 & 0.573 & 6.800 \\
200000 & 3.840 & 1.389 & 0.192 & 0.0400 & 0.00349 & 0.600 & 6.750 \\
300000 & 3.786 & 1.473 & 0.187 & 0.0401 & 0.00454 & 0.645 & 6.700 \\
Fully fixed & 3.353 & 0.586 & 0.1202 & 0.0444 & 0.00081 & 0.351 & 4.675 \\
\hline
\end{tabular}



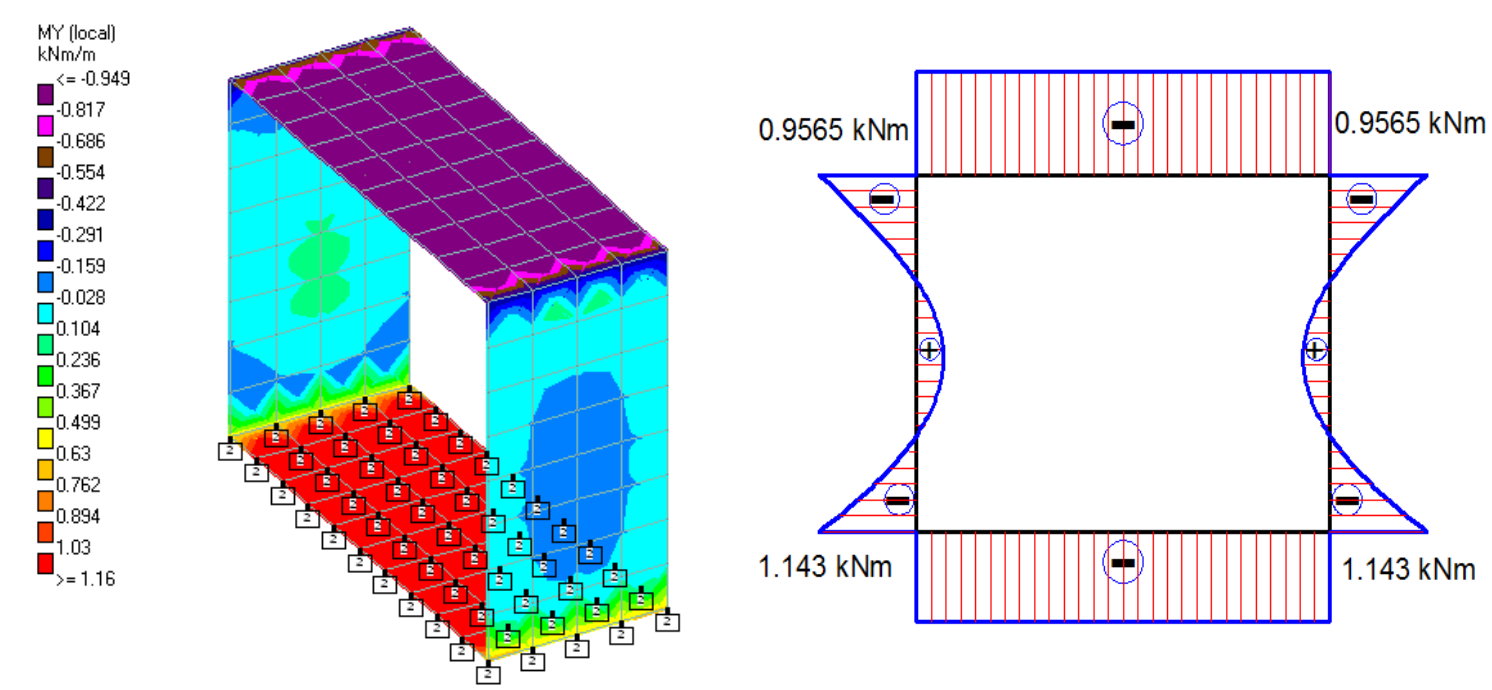

Fig. 7 (a) Bending moment on the culvert for Load Case $3\left(k_{s}=5000 \mathrm{kN} / \mathrm{m}^{2} / \mathrm{m}\right)$ (b) Bending moment on the culvert for non-compressible support according to the formula in [10]

Table 7: Action effects of Load Case 4 under variable soil conditions

\begin{tabular}{lccccccc}
\hline \multirow{2}{*}{ Modulus of Subgrade reaction $\left(\mathrm{kN} / \mathrm{m}^{2} / \mathrm{m}\right)$} & \multicolumn{3}{c}{$\begin{array}{c}\text { Bending Moment } \\
(\mathrm{kN} . \mathrm{m} / \mathrm{m})\end{array}$} & \multicolumn{2}{c}{ Shear Stress (Mpa) } & \multicolumn{2}{c}{$\begin{array}{c}\text { Axial Force } \\
(\mathrm{kN} / \mathrm{m})\end{array}$} \\
\cline { 2 - 8 } & $\mathrm{M}_{\mathrm{x} \text {, max }}$ & $\mathrm{M}_{\mathrm{y}, \max }$ & $\mathrm{M}_{\mathrm{xy}}$ & $\mathrm{Q}_{\mathrm{x}, \max }$ & $\mathrm{Q}_{\mathrm{y}, \max }$ & Wall & Slab \\
\hline 5000 & 1.903 & 0.539 & 0.0813 & 0.0158 & 0.000642 & 0.384 & 5.225 \\
20000 & 1.898 & 0.550 & 0.0807 & 0.0158 & 0.000714 & 0.384 & 5.225 \\
50000 & 1.889 & 0.569 & 0.0796 & 0.0158 & 0.000852 & 0.384 & 5.225 \\
75000 & 1.883 & 0.585 & 0.0788 & 0.0159 & 0.000961 & 0.384 & 5.225 \\
100000 & 1.876 & 0.599 & 0.0799 & 0.0159 & 0.00106 & 0.384 & 5.225 \\
150000 & 1.864 & 0.625 & 0.0764 & 0.0159 & 0.00135 & 0.384 & 5.225 \\
200000 & 1.853 & 0.648 & 0.0750 & 0.0159 & 0.00163 & 0.384 & 5.225 \\
300000 & 1.835 & 0.688 & 0.0727 & 0.0160 & 0.00212 & 0.384 & 5.225 \\
Fully fixed & 1.663 & 0.284 & 0.0575 & 0.0179 & 0.000549 & 0.327 & 4.200 \\
\hline
\end{tabular}

\section{CONCLUSION AND RECOMMENDATION}

From the study conducted on the effect of soil compressibility on the structural response of box culverts, the following conclusions can be reached;

(1) Bending moment values in the box culvert increased with soil modulus of subgrade reaction. The lowest increment was found in gravity load cases in the range of $0.97 \%$ to $1.25 \%$, while the largest increment was found in lateral load cases at about $21 \%$.

(2) Bending moment values for foundations undergoing support settlement showed good agreement with the formulas presented in Reynolds and Steedman [10] for highly compressible soils, but a wide difference ranging from about $9 \%-14.5 \%$ was observed for noncompressible soils. Formulas from Reynolds and
Steedman [10] yielded considerably higher values for non-compressible soils.

(3) The term 'highly compressible' that was used in Reynolds and Steedman [10] is more valid for lateral load cases than for gravity load cases. For gravity load cases, all values of support settlement yielded very close values of bending moment (variation $\leq 1.25 \%$ ). Therefore the formulas in Reynolds and Steedman [10] for gravity load cases are better described as being for foundations that are 'compressible'.

(4) For all load cases considered, twisting moment (torsion) reduced with increase in modulus of subgrade reaction.

(5) The response of box culverts to shear was discovered to be dependent on the nature of the load case. However, where shear stresses 
varied, they were discovered to increase with modulus of subgrade reaction.

(6) Variation in soil compressibility has no significant effect on the axial forces developed in box culverts for symmetrical load cases. However, for load case 3, axial force in the wall was found to increase with modulus of subgrade reaction, while axial force in the slab was found to reduce with modulus of subgrade reaction.

Based on the results from this study, it is recommended that compressible soil conditions be used for analysis of box culverts, since it gave the most realistic scenario in terms of structural response. Staad Pro software and formulas from [10] can be reliably used for this purpose. Further studies should incorporate the effect of ground water and mobilisation of wall friction on soil-structure interaction of box culverts.

\section{REFERENCES}

[1]. NRA BD 31/14 "The design of buried concrete box and portal frame structure". National Roads Authority, Transport Infrastructure Ireland (TII). Publication number AM-STR06029Volume 3 Section 5 Part 8, 2014

[2]. Ahmed A.O.M., Alarabi E. "Development formulation for structural design of concrete box culverts". ASCE Practice Periodical on Structural Design and Construction (16), 48-55,2011

[3]. Abuhajar O., El Naggar N., Newson T. "Numerical Modeling of Soil and Surface Foundation Pressure Effects on Buried Box Culvert Behaviour"ASCE Journal of Geotechnical and Geoenvironmental Engineering. 142(12), pp1-13, 2016

[4]. Reynolds C.E., Steedman J.C., Threlfall A.J. Reynolds' Reinforced Concrete Designer's Handbook $11^{\text {th }}$ Edition. Taylor and Francis, New York, 2008

[5]. Chanakya P., Naidu C.D. "Design aids of RCC box culvert by using Staad Pro"International Journal for Research in Applied Science and Engineering Technology 6(11) pp632-642, 2018

[6]. Krishna P.L., Rajasekhar K. "Analysis and Design of Box Culvert" International Journal of Science Technology and Engineering 4(10) pp141 - 156, 2018

[7]. Chandrakant L.A., Malgonda P.V. "Finite element analysis of box culverts" International
Journal of Advanced Technology in Engineering and science 2(6) pp93 - 102, 2014

[8]. Sinha B.N., Sharma R.P. "RCC box culvert Methodology and designs including computer methods". Journal of the Indian Road Congress. Paper No 555 pp 189-219, 2009

[9]. Shende P., Chudare M. "Analysis of RCC culvert by using software"International Research Journal of Engineering and Technology 05(04) pp 2371-2375, 2018

[10]. Reynolds C.E., Steedman J.C. Reinforced Concrete Designer's Handbook. $10^{\text {th }}$ Edition, E \& FN Spon, Taylor and Francis, London, 2005

[11]. Bentley Systems "Staad Pro V8i Technical Reference Manual". Bentley Systems Incorporated, 685 Stockson Drive, Exton PA, 2012

[12]. Umesh R., Divyashree M. "A comparative study on the sensitivity of mat foundation to soil structure interaction. International Research Journal of Engineering and Technology 05(04) pp 3592-3596

[13]. Worku A. "Winkler's single-parameter subgrade model from the perspective of an improved approach of continuum based modelling". Journal of EEA (26) pp 11-22, 2009

[14]. Bowles J.E. Foundation Analysis and Design $5^{\text {th }}$ Edition McGraw-Hill New York, 1996

[15]. Barounis N., Orr T.L.L., McMahon P.H., Barounis A. "Modulus of subgrade reaction for foundations on clay from unconfined compression strength"In Hamza et al (Eds) In Proceedings of the $1^{\text {th }}$ International Conference on Soil Mechanics and Geotechnical Engineering,Alexandria Egypt pp 249-252, 2009

[16]. Walker W.W., Holland J.A. "Modulus of subgrade reaction - which one should be used?"Engineering Bulletin, Structural Services Incorporated, 2016

[17]. Murthy V.N.S. Textbook of Soil Mechanics and Foundation Engineering. $1^{\text {st }}$ Edition CBS Publishers and Distributors Pvt. Ltd, India, 2012

[18]. Sahu K.K., Sharma S. "Comparison and Study of different aspect ratio of box culvert"International Journal for Scientific Research and Development 3(07) pp 167-175, 2015

[19]. Structural Calculations Ensemble (SCALE) Version 3.45, SCALE Proforma, Fitzroy Computer Systems UK, 2003 